This PDF is a selection from a published volume from the National Bureau of Economic Research

Volume Title: Housing and Mortgage Markets in Historical Perspective

Volume Author/Editor: Eugene N. White, Kenneth Snowden, and Price Fishback, editors

Volume Publisher: University of Chicago Press

Volume ISBN: 0-226-07384-X (cloth); 978-0-226-07384-2 (cloth); 978-0-226-09328-4 (EISBN)

Volume URL: http://www.nber.org/books/fish12-2

Conference Date: September 23-24, 2011

Publication Date: July 2014

Chapter Title: Dutch Securities for American Land Speculation in the Late Eighteenth Century

Chapter Author(s): Rik Frehen, William N. Goetzmann, K. Geert Rouwenhorst

Chapter URL: http://www.nber.org/chapters/c12795

Chapter pages in book: (p. 287 - 304) 


\title{
Dutch Securities for American Land Speculation in the Late Eighteenth Century
}

\author{
Rik Frehen, William N. Goetzmann, \\ and K. Geert Rouwenhorst
}

\subsection{Introduction}

Dutch investors have historically played an important role in American finance. The financiers of the American Revolution turned to the Dutch markets for loans to support their war effort and, with Hamilton's visionary restructuring of the American debt, the Dutch early faith in American promises paid off handsomely. On the heels of their successful financial investment in early US government bonds, Dutch investors in the 1790s turned their attention - and money - toward the speculative potential of the American land itself. Two of the most important foreign investments in American land development prior to the nineteenth century were the Dutch loans for the purchase of vast tracts of lots in the newly designated capital city of Washington, DC, and the Holland Land Company loans to purchase, promote, develop, and resell large sections of western New York State, with tracts that included the future Erie Canal. Both of these projects

Rik Frehen is an assistant professor in the Finance Department at Tilburg University. William N. Goetzmann is the Edwin J. Beinecke Professor of Finance and Management Studies and director of the International Center for Finance at the Yale School of Management and a research associate of the National Bureau of Economic Research.

K. Geert Rouwenhorst is the Robert B. and Candice J. Haas Professor of Corporate Finance and deputy director of the International Center for Finance at the Yale School of Management.

We would like to thank the librarians at the Stadsarchief in Amsterdam, the Gemeentearchief Rotterdam, and the Universiteit van Amsterdam archief for their assistance. We thank Frans Buelens, Ed Glaeser, Oscar Gelderblom, Kim Oosterlinck, and the participants in the 2011 NBER conference and the 2012 Conference on the History of Business and Finance at the Toulouse School of Economics for suggestions. For acknowledgments, sources of research support, and disclosure of the authors' material financial relationships, if any, please see http:// www.nber.org/chapters/c12795.ack. 
were financed by the public issuance of securities that traded on the Dutch capital market.

While Washington, DC's early development and the operations of the Holland Land Company have both been studied from the perspective of American economic history, few studies have taken the perspective of Dutch investors, and asked what motivated them to invest, what precedents existed for these novel and presumably highly risky ventures, how their investments fared over time, and what impact the experience had on future securitizations. The loans offer a rare opportunity to study the process of financial innovation - particularly innovation in the collateralization of real property.

In 1793 and 1794, several complex debt securities called "negotiaties" were floated in the public capital markets of Amsterdam and Rotterdam to finance the two American land projects. The Washington, DC, loans were made to the American financier James Greenleaf who had earlier been instrumental in arranging US government loans on the Dutch market. The Holland Land Company loans were made by a consortium of major Dutch merchants, many of whom had been involved in underwriting and pooling US government debt issues in the Netherlands.

The land negotiaties involved multiple forms of collateral to address different types of risks implicit in the investment, as well as legal and custodial arrangements designed to mitigate fraud and operational failure. In this chapter we examine the terms, conditions, markets, and legal framework of these securities. We document their financial precedents and show how they relied on the rapidly evolving financial institutions of the time.

Our analysis tells the story of both success and failure. The first land venture capitalized by public securities - the Holland Land Companysurvived for more than half a century and generated substantial economic returns to investors; however, a structural reorganization within a decade of its creation was necessary to make it work. The second - the James Greenleaf venture to buy and develop lots in the District of Columbia, in partnership with Robert Morris and John Nicholson - ultimately defaulted and the ensuing transatlantic legal dispute over the collateral dragged on for decades. Dutch investor losses arose not only from default, but also from fraudulent manipulation by Greenleaf and ineffective protection of investor rights by the American legal system, which significantly reduced recovery from the collateral.

We argue that the restructuring of one set of securities and the failure of the other is due to the path dependency of Dutch financial innovation and the mismatch between fixed-income financing and land speculation. Although the market in late eighteenth-century Holland had apparently become comfortable with mortgage-backed securities, perhaps it should not have been. Equity finance, as opposed to debt finance, might have better served investors. Consistent with this hypothesis, we show how both firms sought to convert to equity-like financing in the years after issuance. 
In particular, the Holland Land Company used a restructuring technique previously employed to provide a residual claim on assets in a closed-end portfolio. Greenleaf and his fellow entrepreneurs in the Washington, DC, enterprise, Robert Morris and John Nicholson, were deeply indebted as a result of numerous land speculations. Shortly after their Washington, DC, venture they attempted to pool their property assets and float a public offering of equity shares in the North American Land Company to American and European investors. They were unsuccessful and went to debtor's prison.

Our use of historical evidence to examine financial innovation is not new. A number of researchers have pointed out that there is much to learn about mortgage securitization from the historical mortgage market (cf. White, chapter 4, this volume; Snowden 1995, 2010; Fishback, Horrace, and Kantor 2001; Goetzmann and Newman 2010). The benefit of focusing on the late eighteenth-century Dutch market is that the process of innovation can be clearly traced in historical documents and in public security price quotations. The richness of the historical material allows us to identify specific precedents to innovation. It also allows us to observe the social and business network in which the innovations appeared and diffused.

\subsection{Historical Background}

Our overview of the eighteenth-century Dutch capital markets is necessarily brief and will focus on the appearance of publicly traded, collateralized financial instruments, which is the specific context in which the innovation we study appears.

\subsubsection{Asset-Backed Securities}

An important precedent for the American property securities studied in this chapter is a class of loans collateralized by the revenue stream of the sale of commodities. An early example is the 1659 security issued by Johan Deutz to the House of Austria, which was financed by a loan issued at 4 percent, and collateralized by a monopoly given to Deutz over the product of Austria's rich quicksilver mines. In effect, the loan was a means to secure the monopoly, rather than the principal source of profit by Deutz. ${ }^{1}$ The demand of commodity security for a loan is not surprising in this example, but the financing of the transaction by Deutz's loan issue is noteworthy in that Deutz's credit was enhanced not only by the commodity, but his ability as a merchant to benefit from the monopoly and thus reduce the uncertainty of loan repayment.

This commodity-backed structure eventually became a standardized financial product in the Amsterdam market. In the early eighteenth century, Dutch merchants faced a competitive global market for key commodi-

\section{Barbour (1950, 109).}


ties from the Americas - particularly sugar and coffee. The erosion of the monopoly of the Dutch West Indies Company over Atlantic trade to the Netherlands led to the emergence of independent plantation owners in Surinam, Essequibo, and Demerary, and in certain Caribbean islands such as St. Eustacia. These independent plantations were financed with innovative securities for which the Deutz Austrian loan set a clear precedent. From 1753 to 1795 (when the Dutch relinquished sovereignty over their South American plantations), Dutch merchants floated over 240 "plantation loans" in the public markets. These were debt investments in sugar plantations of Dutch South America and the Caribbean that were collateralized by mortgages on the overseas properties (including land, slaves, and capital equipment), and the annual commodity production of the plantation. ${ }^{2}$

An interesting feature of plantation loans is that the merchants in the commodities trade functioned as financial intermediaries in what we might now call "structured products," which were broadly referred to as negotiaties. The merchant underwrote the issuance of the loans to the public and served as the administrator and servicer, and as the merchant for the commodities on the exchange. His compensation was a commission on sales of the plantation produce while the rest of the sale proceeds were used to service the debt. Van der Voort (1973) notes that the typical interest rate paid by the planters was 5 to 6 percent, and the rate paid to bond holders was fixed as well. The first of the plantation loans was floated by William Gideon Deutz in 1753 - evidently building on his firm's knowledge and reputation from the Austrian loan. This innovation spread to other issuers. According to Van der Voort, ultimately 76 to 80 million guilders of plantation loans were issued by a large number of merchant houses and standard measures of investment safety were applied in the issuance-including a maximum loan-to-value ratio. They took many forms, and issuers would often pool the mortgages from several plantations into a single negotiatie.

A drop in commodity prices in 1771 and a financial crisis in the Amsterdam market in 1773 led to widespread defaults on plantation negotiaties, and a drop-off - though not a complete disappearance - in their issuance. Van der Voort estimates that investors suffered substantial losses, recovering only one-fourth of their capital and realizing no more than 3 percent interest. This event was undoubtedly the first mortgage-backed securities crisis. It is interesting from an institutional standpoint because it revealed to the Dutch market the potential for the failure of collateralized bonds to guarantee full or even significant recovery of capital. In addition, it caused the restructuring of fixed-income claims, including the issuance of equity-

2. Van der Voort (1973) is a detailed study of the Dutch plantation loans from which this discussion is taken. See the English summary pp. 218-221. A recent master's thesis in English is Hoonhout (2012). The role of the plantation loans in Dutch financial development is discussed in Rouwenhorst (2005). 
like certificates. This model of converting debt to equity was evidently not limited to plantation loan defaults. A security from 1776, recently acquired for the Yale Collection of Financial History, is a receipt for a share in a Swedish iron works that had been financed by debt issuance on the Amsterdam capital market, and a reorganization of the debt claim resulted in an exchange for equity. It is not known how many such exchanges took place, but such a conversion, or at least an equity-like restructuring, would later become useful for the Holland Land Company consortium.

Rouwenhorst (2005) points out that the plantation loans also played a key role as precedents for another Dutch financial innovation of the eighteenth century - closed-end mutual funds. These were negotiaties that offered a stream of interest derived from a portfolio of traded securities. The first of these, Eendragt Maakt Magt, was a purely financial security issued in 1774 by Abraham van Ketwich. It was unrelated to the commodities trade except insofar as it held in its diversified portfolio plantation loans in Essequibo, Berbice, and Danish American islands, along with securitized Danish toll revenues, Russian and German sovereign debt, and Spanish toll revenue bonds.

These loans were not simply pass-through instruments, but fixed-income securities with a stated yield - around 5 percent in many cases. The periodic income from the underlying securities was intended to cover the stated yield. The income from the underlying securities was further expected to pay for a lottery by which random shares in the negotiatie would be retired at values above their face amount. This peculiar feature insured that the return on the pool of bonds stochastically dominated the return distribution for any single loan. As we discuss later, the closed-end fund negotiatie structure was also adapted to the financing of American land speculation.

One important difference between the plantation loans and the American land securities discussed in this chapter is that the American securities were claims on future land sales. They were not a means to finance transatlantic commodity trade, but rather were based upon the financing, development, subdivision, and resale of wilderness property. The plantation loans can be interpreted as a means for Dutch merchants to lay off the capital cost of the plantation generating profitable commodity trade. There appears to have been no reliance on future capital appreciation of the collateral as the grounds for the profitability of the investment. In the case of the Holland Land Company and the Washington, DC, loans, this was precisely the opposite. They yielded no commodities for merchants to trade, and the entirety of the expected economic benefit derived from land price appreciation. Although the American land securities used a similar structure to the plantation loans - land or mortgage-backed securitization - the fundamental nature of the underlying economic benefits differed, and thus the risk and timing of future cash flows differed. 


\subsubsection{Other Precedents}

There are other financial precedents relevant to the issuance of securities in Amsterdam to finance American land purchases. The first is the emergence of land banks in various forms through the eighteenth century. Only a brief overview is offered here. The first land bank proposals were floated in England around the end of the seventeenth century as a means to create money out of real property. One of the early land bank theorists, John Law, regarded the scarcity of money as one of the greatest constraints to commercial development, and the reliance of European economies on the supply of New World silver as a risk to be mitigated by changing the collateral for money from precious metal to real property.

America was one of the first places to implement land banking due to the extreme scarcity of hard specie in the colonies. Beginning in South Carolina in 1712, publicly sponsored land banks - actually, more properly loan offices, since they were not deposit-taking institutions - were created by colonial governments to issue mortgages in paper currency that could ultimately be used to purchase foreclosed properties. Other colonies immediately followed suit. In Boston, a private land bank was launched. Parliament was alarmed that the currency of several colonies traded at a discount, reflecting the market perception of their risk. Among other things, the structure of the land bank system embedded conflicts of interest: local boards appraised properties and made loans. A 1738 mortgage contract for seventy-five pounds issued by the Rhode Island Colony sixth land bank is representative. ${ }^{3}$ The twenty-five-year note at 5 percent interest was issued at a 1:2 loan-to-value ratio as determined by a panel of six trustees acting for the general assembly of the colony. The borrower, Edward Arnold, received paper notes for his pledge, which circulated in the colony. His interest payments, along with other borrowers who made up the 100,000 pound loan issue, were evidently sufficient to cover the annual colonial budget. The incentives of the colonies to operate land banks of this sort were clear. While solving the problem of scare specie, they also provided revenue for government. Related lending represented an obvious problem. Parliament outlawed land banks by 1741 and ultimately they were closed.

Land banks did not make a significant reappearance until the end of the ancient regime and the creation of France's revolutionary currency, the assignats. ${ }^{4}$ Dutch investors in 1794 and 1795 would surely have been familiar with the French securities backed by confiscated church properties. By 1795 , the assignats were virtually worthless due to excess issuance and were replaced in the following year by the mandats territoriaux, which likewise rapidly declined in value.

3. In the Yale Collection of Financial History.

4. Cf. White (1995). 
Perhaps more relevant precedents for the American securities were early American land companies. A number of pre- and post-Revolutionary companies were formed to claim, develop, and settle western lands- the Ohio Company launched by a group of powerful Virginians being among the most well known. These firms were essentially private equity share-based companies that could conceivably have served as a model for Dutch investors as well. Livermore (1939) argues that they were innovative corporate structures in their own right. The American agent of the Holland Land Company, Theophile Cazenove, began purchasing shares in American companies in the 1790s. Besides toll and bridge companies, he bought shares in the Pennsylvania Population Company founded by Pennsylvania's comptroller general, John Nicholson, in 1792-partner to Greenleaf and Morris in the Washington, DC, venture. As such, the Dutch consortium comprising the Holland Land Company was familiar with this form of public equity, and perhaps based their own organization on it. The Holland Land Company was itself divided into transferable shares, although there is no evidence that the shares traded on public markets.

Although Dutch financiers were not known to be involved in the American land bank experiment or the French assignat system-except perhaps as speculators - these models are relevant in that they demonstrate the active use of property as collateral for publicly traded debt, whether interestbearing securities or paper money. They indicate that securities collateralized by land were not unknown at the time of the Dutch land loans. However, while there were clear precedents for property-backed securities in the European markets in the late eighteenth century, investor experiences with them may not have been favorable.

Finally, another relevant precedent is the Landschaften of eighteenthcentury Prussia studied by in this volume (chapter 9) and elsewhere by Kirsten Wandschneider. She traces the development of these land credit associations to a financial crisis in 1770 that required the restructuring of debt of the landed nobility. This was accomplished through the issuance of public bearer bonds backed by mortgages held by the Landschaften. Wandschneider likens them to modern "covered bonds," which have recently been proposed as safer alternatives to mortgage-backed debt. Undoubtedly, these were also known to Dutch financiers in the 1790s.

\subsubsection{Dutch Investment in American Debt}

The story of Dutch investment in the debt of the early United States is well described by Riley (2009). The first underwriters of American loans in the Netherlands were the firms of W. \& J. Willink, N. and J. van Staphorst, and De la Lande and Fynje, who floated loans for the United States in 1782. These Dutch intermediaries earned commissions as high as 8 percent for the early flotations and 3 to 5 percent for later loans.

Even more profitable was the speculation on domestic debt of the United 
States, which Dutch merchants bought at steep discounts at the nadir of American creditworthiness prior to Hamilton's reorganization of the debt. Over the period 1782 to 1794, Dutch speculators issued a number of negotiaties on the Dutch capital markets backed by the bonds of the United States. These American negotiaties typically paid a promised rate of interest and were secured with US securities held in trust. Riley points out that the first movers in this securitization of American debt were also major boosters of America. Pieter Stadnitski, a member of the Dutch Patriot faction ultimately aligned with the French Revolution, was not only a major purchaser and securitizer of US bonds but also an enthusiastic pamphleteer who wrote glowingly about the new American democracy and the wonderful American land. Riley calculates that Stadnitski made a killing by buying American paper at 37.5 percent of face value and selling it at 60 percent of face value to investors in his negotiaties. Investors in his funds also profited as the prices of the negotiaties rose in the Dutch market as a result of the strengthening of American finances. Stadnitski's arbitrage was rapidly imitated by other merchants and, not surprisingly, spreads narrowed.

An important feature of these American fund negotiaties is that they provided for a distribution of residual profits deriving from the purchase of US bonds at a discount. As prices of the United States' debt rose to par, the capital gain accruing to investors - even after the issuers took their cut as intermediaries - was substantial. Thus there was some "right-tail" to the distribution of expected returns to investing in the debt of the young United States. Their popularity with the Dutch public may have been due as much to this feature as to the conviction that the United States was certain to meet its obligations.

The firm of Daniel Crommelin and Sons in Amsterdam was among the several issuers of negotiaties backed by US notes. He was aided in this operation in 1794 by an American merchant from Boston, James Greenleaf. Greenleaf was married to a daughter of a member of a prominent Amsterdam banking family and served as US consul to the Netherlands. He knew the Crommelin family through their mercantile dealings in the United States. An American branch of the family was stationed in New York, where part of Greenleaf's business was also located.

\subsection{Financial Innovation: American Property Securities}

The rich data in Dutch archives and the considerable historical research devoted to the history of the Holland Land Company and to the early development of Washington, DC, make it possible to trace in detail the process of innovation leading to the issuance of its securities on American speculative lands. This section describes the development of these securities and their contractual details. 


\subsubsection{Holland Land Company Negotiaties}

In 1789 a consortium of leading merchant houses formed to explore land purchases in America. The firms of Stadnitski, Van Staphorst, Van Eeghen, and Ten Cate \& Van Vollenhoven had all made money buying American funds and issuing negotiaties. Perhaps equally relevant, the investors to whom they had sold negotiaties backed by American debt securities also made money. As mentioned earlier, the consortium employed an agent to travel to America, Theophile Cazenove, who scouted opportunities and began to invest the firm's capital, initially into American share companies. These included shares in the Pennsylvania Population Company and shares in the James River Company - a firm nominally headed by George Washington to improve the navigation of the James River for development of the commercial traffic into the southern Virginia piedmont. In April 1791 the Holland Land Company joint ventured with the Rotterdam firm of Van Beefting and Boom to explore sugar maple operations with the hope of establishing another source of commodity production in the American forests. Cazenove, perhaps due to his involvement with John Nicholson, also became interested in purchasing undeveloped land for division and sale to immigrants and US settlers. In December of 1792, the Dutch consortium bought 3,300,000 acres in the Genesee River valley from Robert Morris. That year the Holland Land Company was created. The five firms brought in the Van Willinks and retained Rutger van Schimmelpenninck as legal advisor. ${ }^{5}$ The share company was formed among the participants and the shares were not publicly traded, so it was, in effect, a private equity company. The firm further formalized its structure in 1796.

The first public financing of the Holland Land Company was a subscription of negotiaties of 3,000,000 guilders floated in January 1793 on one million acres of land in the Genesee valley, which was valued (or transferred to the trustees of the negotiatie) at 1.2 guilders per acre. In addition 1,200,000 guilders in American funds was transferred to the trustees to cover the costs of paying interest over the first five years. The first issue was completely subscribed, and a second followed in June. ${ }^{6}$

The Holland Land Company offering was promoted by a pamphlet published by Stadnitski extolling the virtues of America, describing the particulars of the settlement process and projections about an increase in the demand for land. Evans $(1924,28)$ notes that Stadnitski's pamphlet

5. This account is taken from Evans (1924, and ff).

6. Details of the offering can be found in Nieuwe Nederlandsche jaerboeken, of Vervolg der merkwaerdigste geschiedenissen: die voorgevallen zyn in de Vereenigde provincien, de generaliteits landen, en de volkplantingen van den staet. 1.-33. deel, 1766-98, Volume 2. P. 1442. Also see the certificate Amsterdam City Archives, archive no. 333 "Holland Land Company," inventory no. 867 "Shares of various negotiations." 
describes the speculative profits Morris himself had made - tripling his investment in a million acre purchase via a sale to the British Pultney Company. Accompanying this pamphlet were calculations of expected profits of more than 200 percent over a nine-year horizon accruing to an investment in 400,000 acres of land in the Genesee valley. Important to our analysis is that this spreadsheet, almost certainly prepared by Stadnitski for a French investment market, shows no positive cash flow for the first five years. Even in an optimistic scenario capital investment was required; hence the necessity of substituting a portfolio of US debt to address the problem of the mismatch between duration of the debt and the assets. The management fees, in addition to costs, were 1 percent for startup (up front), and .5 percent for payment of dividends.

The Holland Land Company negotiaties are puzzling in several respects. First, they did not promise any economic benefits from future land sales, other than meeting interest payments. This suggests that the market demand for the securities was not based on an expectation of speculative profits from development of the American frontier. The debt structure was clearly not due to lack of knowledge about equity financing. Cazenove was already purchasing American equity securities on the firm's behalf. Essentially the negotiatie provided leverage for the consortium to buy American lands, and a portion of their property was pledged as collateral. The Stadnitski financial forecast makes it clear that the firm understood that, even under an optimistic scenario, for the first years of operation cash flow would be negative, necessitating the inclusion of American government securities to meet promised interest payments in the first few years of operation.

Also puzzling is why Dutch subscribers to the Holland Land Company issues would take such significant risks for a relatively modest yield. It is unlikely that, in the event of default, the property in the wilderness of New York could be easily liquidated by creditors, when the borrowers were unable to do so. Perhaps the reputation of the borrowers and the recent returns to investments in American debt provided additional implicit promise of fulfillment.

Going forward, the Holland Land Company bonds met their minimal obligations by paying interest through 1798; however, land sales necessary to extend the interest payments did not materialize. In 1804 the combined cash reserves for the two loans had decreased to 520,000 Florins due to a combination of large investment in the enterprise, poor cash flows from land sales, and a high burden of interest payments. ${ }^{7}$ As a consequence the company faced a large debt overhang, which resulted in a strong disincentive to the equity owners of the company to continue. This led to an offer of a major restructuring of the negotiaties.

7. Evans $(1924,430)$. 
The restructuring involved a merger of the two negotiaties that was in part motivated by a conflict of interest between the two investor groups, who developed a preference for the January negotiatie over the June issue. The lands of the January negotiatie included the headquarters of the company, which caused the surrounding lands also owned by the January negotiatie to trade at a premium. The merger put the two investor groups back on equal footing. But more importantly, the complex restructuring of the negotiaties was an attempt to mitigate the debt overhang. The proposal was for a repurchase agreement to reduce the debt burden in return for an opportunity for investors to participate in the residual profits of the land sales. In particular, the company offered investors a lottery to buy back their shares at a steep discount ( 40 percent or 35 percent of par), but investors were not required to participate. Investors who elected to participate and whose shares were drawn by lot would receive an equity stub to share in the final distribution of the residual profits of land sales at the end of the negotiatie's term. ${ }^{8}$ Investors who participated likely believed that their interests were better served by owners and equity holders who were granted debt relief and renewed incentives to develop lands going forward, and perhaps the prospect of some participation in the upside of the fortunes of the company after a period of disappointing results. In the end a two-thirds majority of the bondholders accepted this exchange.

Our archival study shows that the well-known merchant houses that floated the Holland Land Company were among the first subscribers to the lottery scheme. Perhaps they aimed to signal other bond holders that subscription would be to their benefit. Although it is unclear to what extent lottery subscriptions were public knowledge, making lottery subscriptions public would have both a positive and negative effect on future lottery subscriptions. On the one hand, it may serve as a validation by revealing that many of the prominent financiers have subscribed. On the other hand, once a large number of bond holders have subscribed, unsubscribed bonds may benefit from an expected drop in default risk triggered by a reduction in debt overhang.

The firm ultimately retired all 3,000 shares of the negotiatie, as planned, and in addition there was a substantial residual value. Over a twenty-year period, it made periodic payments to investors based upon land sales, which finally wound up in 1858 . The amount investors received in total was $6,673,447.5$ F. Evans claims that investors made a reasonable return on their investment in the long run, although this interpretation depends on selection of a risk-appropriate discount rate.

8. The merger agreement separately stipulated that the company might subsequently try to buy back shares below par in the open market (in which case investors would not participate in the equity residual) or at par, in which case investors would get an equity stub. 


\subsubsection{A Closed-End Fund Negotiatie}

As part of its restructuring in 1805, the Holland Land Company also issued a closed-end fund negotiatie to raise capital. ${ }^{9}$ To our knowledge this fund is previously unreported in the literature on the Holland Land Company. The negotiatie enumerates three different securities for lands in the state of New York - two issued by members of the Holland Land Company consortium and one by the Holland Land Company itself - presumably one of the two mortgage-backed securities discussed earlier, but perhaps alternatively a share in the consortium itself. It also lists two American land company stocks (the St. James River Company and the Pennsylvania Population Society) and a bond issue of the state of South Carolina. These securities were held in trust, and the proceeds from their interest, dividend payments, and future sales were used to benefit two classes of investors. The first class received 5 percent annual interest and were redeemed by lot. The second class received no interest payments, only the residual value from the underlying securities. This rendered the second class of investors in the negotiatie equity claimants.

This structure is interesting for several reasons. First it shows the shares in the American land companies purchased by Cazenove were ultimately monetized by the Holland Land Company through what we would today call a "structured product." Second, it indicates that the founding investors in the Holland Land Company monetized their holdings through issuance of negotiaties that were not evidently quoted on the Amsterdam exchange (as were the Holland Land Company 1793 issues). Third, it indicates that, by 1805, there was a demand for equity-like claims on American land speculation. As such, it may be further evidence of a transition to separating debtlike and equity-like financing of land ventures around this time.

\subsubsection{Washington, DC, Bonds}

In 1793, the success of the Holland Land Company negotiatie clearly set a precedent for James Greenleaf's loan. In that year, Greenleaf began to negotiate for the purchase of 3,000 lots in the new national city of Washington, DC, while concurrently seeking financing from his former Dutch associates using a vehicle very much like the Holland Land Company securities. As with the Holland Land Company negotiaties, this involved two types of collateral: one for the interest payments to investors and another for the assets of the negotiatie. Both were held in trust. His efforts at soliciting Dutch financing resulted in two negotiaties - one issued in Amsterdam by the firm of Daniel Crommelin and Sons and the other in Rotterdam issued by Rocquette, Elzevier, and Beeldemaker. 
Following the pattern of the Holland Land Company group, Greenleaf undertook this issue after purchasing property in partnership with two other investors, both major real estate speculators: Robert Morris, former superintendent of the US Treasury, and John Nicholson, former comptroller general of the Commonwealth of Pennsylvania. Neither is named in the Dutch issues, which treat Greenleaf as the sole borrower. Morris had earlier sold the land in New York to the Holland Land Company and Nicholson was involved in several land company schemes including the Pennsylvania Population Company in which the Holland Land Company principles had invested. Thus all three partners were familiar to Dutch financiers. Greenleaf purchased 3,000 lots in September of 1793, for twenty-five pounds per lot, with terms allowing him to make annual payments over the following seven years at zero interest. ${ }^{10}$ In December, Robert Morris contracted for an additional 3,000 lots on the same terms at thirty-five pounds each. Arbuckle (1975) calculates that these 6,000 lots encompassed 42 percent of the available property in the capital city. ${ }^{11}$ The structure of the partnership between Greenleaf, Morris, and Nicholson is unclear.

The terms of the Amsterdam loan are known from the proposal drawn up by Greenleaf and presented to the firm of Daniel Crommelin and Sons. ${ }^{12} \mathrm{He}$ proposed a two million guilder loan with a term of twelve years, for which he offered as collateral the 3,000 house lots purchased from the city of Washington, DC. To guarantee the interest on the loan over the first six years of the term of the loan, he offered as collateral a portfolio of US government debt and other securities. He had the right to redeem debt at face value and in so doing redeem a pro rata share of the title to the land held in trust. Thus, the initial conception of the security was strictly a debt instrument.

The exact nature of the collateral structure is interesting. The titles to the financial securities and to the real property were transferred to the trustees of the respective issues. This same structure for the Holland Land Company relied only on a notary who held the land deeds. The transfer of property deeds to Washington, DC, was documented through notarized and witnessed letters from officials in the United States. The squares in which the properties are located were concentrated in the north and east of the city, although Greenleaf's best known development is Greenleaf's Point in the city's southwest.

The trustees for the loan were Peter Godefroy, Daniel Crommelin, and Rutger Jan Schimmelpenninck. Godfrey and Crommelin were the merchant bankers issuing the bond. Schimmelpenninck was a prominent lawyer and politician who, in the year 1795, became the leader of the Patriot revolt in

10. Arbuckle $(1975,117)$.

11. Arbuckle $(1975,118)$.

12. Amsterdam City Archives, archive no. 654 "Archive of the Firm Daniël Crommelin and Sons, since 1859 Tutein Nolthenius and De Haan," inventory no. 106 "Letters from J. Greenleaf, received by A. Gerard, clerk of the Crommelin firm, 1973 and 1794." 
the Netherlands that resulted in the Batavian Republic. He also held shares in the Holland Land Company.

The Rotterdam loan, referred to in the financial press as Rocqette, Elzevier, and Beeldemaker op gronden Washington, was issued on December 15,1794 , and was intended to be for one million guilders and pledged 1,500 house lots. It had a term of five years, a 5.5 percent interest rate, and a similar mortgage and trustee structure to the Amsterdam loan. A lottery structure of the Rotterdam loan was not tied to the value of the properties but instead simply paid a premium of face value for bondholders chosen by lot. These premia show strong similarities to modern lottery plans and were paid out conditional on full repayment by the loan according to the following structure:

- 10 premia for 100 percent

- 10 premia for 50 percent

- 20 premia of 25 percent

- 50 premia of 20 percent

- 90 premia of 10 percent

- 220 premia of 5 percent

Held open for subscription over the first several months of 1794, the loan was ultimately undersubscribed and the terms adjusted accordingly. While the issuers originally planned to raise 1,000,000 guilders in capital and connect 1,500 lots within the city of Washington, DC to the loan, market sentiment evidently only allowed them to raise 150,000 guilders and the number of lots was proportionally reduced to 225 , a total of 668,250 square feet.

All lots were transferred in the names of custodians Gillis Groeneveld, Rudolph Mees, and Pieter van der Wallen van Vollenhoven and posted as collateral to the loan with an act of renunciation to protect the investors. The deeds of transfer by Sylvanus Bourne, "on behalf of the gentlemen Groeneveld, Rudolph Mees and Pieter van der Wallen van Vollenhoven" of half of the 2,632,000 square feet of lots, all within the city of Washington, DC, are deposited with the notary, as collateral for the negotiatie. These lots were bought by consul Greenleaf on July 29, 1794. Together with these deeds, the notary received all documents needed to transfer a sufficiently large portion of property in to the aforementioned custodians. Interest on the loan was 5.5 percent, secured through US sovereign debt certificates in the names of Rocquette, Elzevier, and Beeldemaker. In addition to the US debt certificates and Washington, DC, property, James Greenleaf was held personally liable for the loan.

The Amsterdam loan collected only 200,000 guilders and the Rotterdam loan collected only 150,000 guilders. The fees of the Amsterdam investment issuers are not known from the surviving documents. The so-called directors of the Rotterdam loan incurred a 1 percent setup fee and .5 percent per dividend. 
The failure of the Greenleaf flotations is variously attributed to the turmoil of the Dutch politics at the time and the invasion of the country by France, but perhaps the market was simply skeptical about a security floated by an American consortium as opposed to a Dutch consortium. In addition, perhaps investors were rightly mistrustful of Greenleaf himself. Evidently Greenleaf did not share the proceeds of the Dutch loans, meager as they were, with the partnership. ${ }^{13}$

In all, 200 bonds were issued by Crommelin in Amsterdam with a face value of 1,000 guilders. The list of subscribers contains the names of other merchant houses of the day, including bankers. Unlike preceding US debt negotiatie issued by Crommelin with Greenleaf, there are no surviving certificates and thus they may not exist, although the legal rights of the holders are summarized in the "Nieuw Nederlandse jaerboeken" as previously indicated. From the period 1796 through 1811, the Amsterdam Pryscourant quoted bid and ask prices for the two Washington, DC, negotiaties on a regular basis.

The story of the Greenleaf, Nicholson, and Morris bankruptcies is a fascinating one that will not be recounted here. Essential to our analysis is the step they took on February 20, 1795, (the year following the loans) to launch the North American Land Company. Each partner contributed property to the company totaling 4,479,317 acres. These properties were held in trust, and shares were issued to the founders. While attempts were evidently made to float a public offering of shares in the North American Land Company in US markets and in the Netherlands, relatively few shares were issued and these evidently to creditors of the two men. ${ }^{14}$ Greenleaf sold his shares in 1796 to his partners for $\$ 1,500,000$ in notes, although he remained connected with the business of the firm for many years as it wound up. He represented its business interests after the death of his former partners. In addition, he ultimately represented the business interests of the Dutch claimants to the Washington, DC, lots.

The holders of the Dutch negotiatie expected to be shielded from the tribulations of Greenleaf and company by virtue of having title to the properties in trust, and the guarantee of the US securities to cover promised interest payments. The Dutch title to the lots was later challenged due to Greenleaf's conveyance of the titles prior to performance of his obligations to the US government. Lots were sold under the stipulation that they be built upon. This led to a protracted legal dispute, the necessity of the Dutch investors to retain counsel in America, to meet tax obligations on the lots, and to auction the properties.

Greenleaf outlived his two partners and oversaw the disposition of the assets of the North American Land Company. He continued to develop 
property in Washington, DC, despite his bankruptcy, and ultimately built a number of houses in an area of southwest District of Columbia called Greenleaf Point, some of which still stands today.

Our archival research revealed evidence that Greenleaf took advantage of the Dutch investors on a second occasion. In the 1830s he offered his services to them as a sales agent and contracted to organize an auction of the Washington, DC, lots held in the Rocquette, Beeldemaker, and Elzevier negotiatie. He agreed with the bondholders to split the revenues from the land sales evenly. All taxes and intermediary costs were to be paid by the "Holland gentlemen," however. Greenleaf won these terms after a long negotiation. At the auction in May, 1835, Greenleaf himself bought 50 percent of the property. But since he also got 50 percent of the revenues, he got 50 percent of the land for free. After subtraction of taxes, legal charges, and intermediary costs, what small amount remained was paid out to the bondholders. Rocquette, Beeldemaker, and Elzevier wisely decided not to inform the bondholders (via the account) who actually bought the land, although they likely knew, and could not have been happy that they had been duped yet a second time by James Greenleaf.

In sum, Greenleaf, Morris, and Nicholson's initial difficulties stemmed from their failure to raise sufficient capital to allow them to be patient investors in the development and sale of properties. Like the Holland Land Company, they could not monetize the properties rapidly enough to meet cash obligations. These difficulties may have been compounded by the shady dealings and reputation of one or more of the three partners.

\subsection{Path-Dependent Financial Innovation}

Empirical studies of financial innovation are necessarily limited to unusual events. Frame and White (2004) argue that most analyses of financial innovation are forced to generalize from a few cases. Lerner and Tufano (2011) articulate this problem and use a set of historical examples - from the emergence of the venture capital industry to the appearance of mutual funds, to address the costs and benefits of financial innovation. Their approach considers the counterfactual; that is, what the economy would look like without a specific innovation.

In the first part of this chapter we detailed the many precedents for the Dutch property negotiaties, particularly the debt-like securities and funds issued in the Amsterdam market in the mid to late eighteenth century. We showed how the features of the Holland Land Company negotiaties and the Washington, DC, negotiaties could be traced to particular precedents in the Dutch market. Our hypothesis is that the innovations relied upon the marketplace's prior acceptance of bond-like instruments. This initially precluded offerings of common stock. The debt securities in the Dutch market at the time were characterized by features designed to secure expected future payments, although certain of them also contained "right-skewed" 
payoffs created by lottery features and rights in residual value to portfolios of securities. This framework of innovation is an exemplar of an institutionalist perspective in which frictions and information transactions costs of various types are minimized by reliance on precedent. One corollary is that path-dependent outcomes need not be first-best solutions or optimal in any measurable sense; only that they are improvements on existing technology.

The Holland Land Company found the debt service burdensome and restructured their negotiatie in 1805 into an instrument with an equity-like component, reducing the face value to be repaid and replacing it with a residual claim. They further supplemented this with a closed-end fund issue that partitioned proceeds into debt- and equity-like claims.

Shortly after issuing their two negotiaties, Greenleaf, Morris, and Nicholson also tried to engineer an equity-for-debt swap of their vast but highly levered American property holdings by creating the North American Land Company. This had some institutional precedent in the eighteenthcentury American land, bridge, and canal companies trading on the Philadelphia Exchange - several of which Nicholson himself had been involved in launching. These institutional forms might have encouraged the hope that such a rescue was possible. While the Holland Land Company was less immediately constrained because its first two public offerings had been fully subscribed, it may have been restricted because of the lack of a market for equities in the Dutch market. This may explain the complexities of the 1805 residual claim certificates.

On the one hand, the land company negotiaties in the eighteenth-century Netherlands are extraordinary innovations: early and complex structured mortgage notes that demonstrate the remarkable sophistication of the capital markets of the time. On the other hand, the financial engineering required to make a debt instrument fit the needs of an enterprise whose value proposition is based upon patiently developing a market on the western frontier, or the growth of an entirely new city, is perhaps extremely inefficient. Had these firms been able to issue equity initial public offering (IPO)'s to a market that accepted them comfortably, the outcome - at least for Greenleaf, Morris, and Nicholson, might have been very different.

\subsection{Conclusion}

In this chapter we examine the development of an interesting class of mortgage-backed securities issued in the eighteenth century. Debt instruments evolved to support an innovative merchant tradition that used collateralized securities for financing. We conjecture that the American land negotiaties pushed the existing debt-based financial infrastructure of the Netherlands to its limits. Not designed to finance projects with long verification periods, fixed income issuances were used anyway with negative results, and led to recontracting to create what amounted to equity. This restructuring was successful in one instance, and completely failed in another. 


\section{References}

Arbuckle, Robert D. 1975. Pennsylvania Speculator and Patriot: the Entrepreneurial John Nicholson 1757-1800. State College: The Pennsylvania University Press.

Barbour, Violet. 1950. Capitalism in Amsterdam in the Seventeenth Century. Baltimore: Johns Hopkins Press.

Evans, Paul D. 1924. The Holland Land Company. Fairfield, NJ: Augustus M. Kelley Publishers. Reprint, 1979.

Frame, W. Scott, and Lawrence J. White. 2004. "Empirical Studies of Financial Innovation: Lots of Talk, Little Action?” Journal of Economic Literature 42:116-44.

Fishback, Price V., William C. Horrace, and Shawn Kantor. 2001. "The Origins of Modern Housing Finance: The Impact of Federal Housing Programs During the Great Depression." Working Paper, University of Arizona.

Goetzmann, William, N., and Frank Newman. 2010. "Securitization in the 1920's." NBER Working Paper no. 15650, Cambridge, MA.

Hoonhout, Bram. 2012. "Subprime Plantation Mortgages in Suriname, Essequibo and Demerara, 1750-1800. On Manias, Ponzi processes and Illegal Trade in the Dutch Negotiatie System." Master's Thesis, Leiden University.

Lerner, Josh, and Peter Tufano. 2011. "The Consequences of Financial Innovation: A Counterfactual Research Agenda.” NBER Working Paper no. 16780, Cambridge, MA.

Livermore, Shaw. 1939. Early American Land Companies: Their Influence on Corporate Development. New York: The Commonwealth Fund.

Riley, James. 2009. International Government Finance and the Amsterdam Capital Market, 1740-1815. Cambridge: Cambridge University Press.

Rouwenhorst, K. Geert. 2005. "The Origins of Mutual Funds.” In Origins of Value: The Financial Innovations That Created Modern Capital Markets, edited by William N. Goetzmann and K. Geert Rouwenhorst, 249-71. Oxford: Oxford University Press.

Snowden, Kenneth A. 1995. "Mortgage Securitization in the United States: Twentieth Century Developments in Historical Perspective." In Anglo-American Financial Systems, edited by Michael D. Bordo and Richard Sylla, 261-98. New York: Irwin.

2010. "The Anatomy of a Residential Mortgage Crisis: A Look Back to the 1930s.” NBER Working Paper no. 16244, Cambridge, MA.

Van der Voort, Johannes P. 1973. De Westindische Plantages van 1720 tot 1795, Financian en Handel. Eindhoven, Netherlands: De Witte.

White, Eugene N. 1995. "The French Revolution and the Politics of Government Finance, 1770-1815.” Journal of Economic History 55 (2): 227-55. 